\title{
Anxiety and neurometabolite levels in the hippocampus and amygdala after prolonged exposure to predator-scent stress
}

\author{
O.B. Shevelev ${ }^{1} \otimes$, V.E. Tseilikman ${ }^{2}$, N.V. Khotskin ${ }^{1}$, A.S. Khotskina ${ }^{1}$, G.V. Kontsevaya ${ }^{1}$, M.S. Lapshin ${ }^{2}$, M.P. Moshkin ${ }^{1}$, \\ M.V. Komelkova ${ }^{2}$, I.V. Feklicheva ${ }^{2}$, O.B. Tseilikman ${ }^{2}$, E.B. Manukhina ${ }^{2,}{ }^{3}, 4$, H.F. Downey ${ }^{4}$, E.L. Zavjalov ${ }^{1}$ \\ ${ }^{1}$ Institute of Cytology and Genetics, SB RAS, Novosibirsk, Russia \\ ${ }^{2}$ South Ural State University (National Research University), Chelyabinsk, Russia \\ ${ }^{3}$ Institute of General Pathology and Pathophysiology, Moscow, Russia \\ ${ }^{4}$ Department of Physiology and Anatomy, University of North Texas Health Science Center, Fort Worth, Texas, USA \\ 圆e-mail: shevelev.oleg.nsk@gmail.com
}

\begin{abstract}
Here, to study the relationship between anxiety levels with changes in the neurometabolic profile in the hippocampus and amygdala, an experimental predator stress model was reproduced in which Sprague-Dawley rats were exposed to cat urine for 10 minutes on a daily basis for 10 days. At the time of presentation of the stimulus, an online survey of behavioral reactions was conducted. Fear, aggressiveness, avoidance of stimulus and grooming were recorded. Fourteen days after the completion of the last stress exposure, the total level of anxiety was determined in the test of the "cross maze". Using the method of in vivo NMR spectroscopy, the content of neurometabolites was determined in the hippocampus and in the amygdala. According to the peculiarities of behavioral reactions to a stressor, animals were retrospectively divided into two phenotypes. The first phenotype used a passive behavioral strategy, and the second phenotype was active. In animals of the first phenotype, the indicators of anxiety behavior remained at the control level. In animals of the second phenotype, a decrease in anxiety was observed. Animals of the second phenotype showed elevated levels of lactate in the hippocampus compared to animals of the first phenotype, and the lowest $\mathrm{N}$-acetylaspartate levels significantly differed from those in the control and the first phenotype animals. In the amygdala, in animals of the second phenotype, the content of taurine is sharply reduced in comparison with those in the control and the animals of the first phenotype. Thus, the results obtained indicate a relationship of post-stress changes in anxiety, with the peculiarities of the behavioral reactions presented at the moment of the immediate action of the stressor. Among the hippocampal and amygdala neurometabolites, the most informative for the characterization of the anxiolytic action of the predator stress are identified.
\end{abstract} Key words: predator scent stress; neurometabolites; amygdala; hippocampus; anxiety index.

For citation: Shevelev O.B., Tseilikman V.E., Khotskin N.V., Khotskina A.S., Kontsevaya G.V., Lapshin M.S., Moshkin M.P., Komelkova M.V., Feklicheva I.V., Tseilikman O.B., Manukhina E.B., Downey H.F., Zavjalov E.L. Anxiety and neurometabolite levels in the hippocampus and amygdala after prolonged exposure to predator-scent stress. Vavilovskii Zhurnal Genetiki i Selektsii = Vavilov Journal of Genetics and Breeding. 2019;23(5):582-587. DOI 10.18699/VJ19.528

\section{Уровень тревожности и содержание нейрометаболитов в гиппокампе и амигдале крыс после завершения хронического предаторного стресса}

О.Б. Шевелев ${ }^{1} \otimes$, В.Э. Цейликман ${ }^{2}$, Н.В. Хоцкин ${ }^{1}$, А.С. Хоцкина ${ }^{1}$, Г.В. Концевая ${ }^{1}$, М.С. Аапшин $^{2}$, М.П. Мошкин ${ }^{1}$, М.В. Комелькова ${ }^{2}$, И.В. Фекмичева ${ }^{2}$, О.Б. Цейликман ${ }^{2}$, Е.Б. Манухина ${ }^{2,3,4}$, Г.Ф. Аауни ${ }^{4}$, Е.А. Завьямов ${ }^{1}$

\footnotetext{
1 Федеральный исследовательский центр Институт цитологии и генетики Сибирского отделения Российской академии наук, Новосибирск, Россия

2 Южно-Уральский государственный университет (национальный исследовательский университет), Челябинск, Россия

${ }^{3}$ Научно-исследовательский институт общей патологии и патофизиологии, Москва, Россия

${ }^{4}$ Центр медицинских наук Университета Северного Техаса, Форт-Уэрт, Техас, США

凶e-mail: shevelev.oleg.nsk@gmail.com
}

В этом исследовании для изучения соотношения между уровнем тревожности с изменениями нейрометаболического профиля в гиппокампе и амигдале воспроизводилась экспериментальная модель предаторного стресса, в которой крысы линии Sprague-Dawley в течение 10 минут подвергались экспозиции кошачьей мочи на протяжении 10 дней ежедневно. В момент предъявления стимула велась съемка поведенческих реакций. Регистрировались реакции испуга, агрессивности, избегания стимула и груминга. Через 14 дней после завершения последнего стрессорного воздействия в тесте «крестообразный лабиринт» определялся общий уровень тревожности. С помощью метода прижизненной ЯМР-спектроскопии определяли содержание нейрометаболитов в гиппокампе и амигдале. По особенностям поведенческих реакций на стрессор животные были ретроспективно разделены на два фенотипа. Первый фенотип использовал пассивную поведенческую стратегию, а второй - активную. У животных первого фенотипа показатели тревожного поведения сохранялись на контрольном уровне, в то время как у животных второго фенотипа наблюдалось снижение 


\begin{abstract}
этого показателя. В гиппокампе у животных второго фенотипа отмечалось повышенное содержание лактата по сравнению с животными первого фенотипа, тогда как уровень $\mathrm{N}$-ацетиласпартата имел самые низкие значения, отличные от таковых у животных двух других групп. В амигдале у животных второго фенотипа было снижено содержание таурина по сравнению с животными первого фенотипа и контрольной группы. Таким образом, полученные результаты свидетельствуют о связи постстрессорных изменений тревожности с особенностями поведенческих реакций, выявленных в момент непосредственного действия стрессора. Среди нейрометаболитов гиппокампа и амигдалы определены наиболее информативные для характеристики анксиолитического действия предаторного стресса.
\end{abstract}

Ключевые слова: предаторный стресс; нейрометаболиты; амигдала; гиппокамп; индекс тревожности.

\section{Introduction}

Different kinds of predator stress such as visual contact with a predator and exposure to its scent are considered as experimental models to study post-war stress syndrome and post-traumatic stress disorder (PTSD) (Cohen et al., 2008). What is interesting about this disorder is that PTSD develops electively and a lot of people who have been exposed to severe psychological stress are resistant to PTSD (Pitman et al., 2012). Another interesting neurobiological phenomenon that has been discovered lately, is called post-traumatic growth (PTG) syndrome. This syndrome also develops after a phycological trauma in a relatively small group of patients (Wong et al., 2018). So far, the biological mechanisms making people resistant to both PTSD and PTG have remained unknown.

Developing a proper experimental model remains another crucial issue for studying PTSD. Such models are required to be relevant to the diagnostic criteria (Cohen, Zohar, 2004). According to the fifth edition of Diagnostic and Statistical Manual of Mental Disorders (American Psychiatric Association, 2013) PTSD can be diagnosed after identification of a stressor that triggers the disorder. Since PTSD is a long-term consequence of the stressor's effect, researchers have not paid much attention to a patient's behavioral response to emotional distress when resistance to PTSD is being formed.

Despite the long-term history of investigation into the role of behavioral adaptation strategies in forming response to stressors, PTSD has rarely been studied in this respect. Neurobiology knows two adaptation strategies. The first one is aimed at active overcoming of a stressing situation and is called a stimulus-response or S-R strategy (Schwabe et al., 2008; De Kloet, 2012). The other, adaptive strategy aimed at getting accustomed to a stressor is often called a spatial or S strategy (Schwabe et al., 2008). It is apparent that the S-R strategy is necessary in a situation when a stressor can be surmounted by fight or run, while the S strategy is useful in the presence of a continuous stressor. Following the S-R strategy activates the hippocampus-striatum axis, while transmitting neural signals from the hippocampus to amygdala launches the S strategy (Schwabe et al., 2008).

Most of the studies dealing with the metabolism of these key limbic structures under chronic stress have been conducted in vitro, while modern techniques of NMR spectroscopy enable one to obtain in vivo estimations of the hippocampus and amygdala's metabolic profile. Unfortunately, these have been just a few studies based on the NMR spectroscopy data obtained under chronic stress. Earlier it has been demonstrated (Hemanth Kumar et al., 2012) that chronic stress increases the proportion of some metabolites (myoinositol, taurine) and decreases the proportion of others (N-acetylaspartate, glutamate, glutamine, gamma-aminobutyric acid (GABA)) in the hippocampus. In this study, the changes were measured right after the end of a stressor effect. Unfortunately, no studies investigating the long-term effects of chronic stress on hippocampus and amygdala NMR spectroscopy data have been available so far.

In the presented study we investigated the immediate reaction to a stressor in animals under predator stress. During the investigation, we, first hand, tried to understand whether it was possible to distinguish different behavioral phenotypes with different behavioral strategies in immediate response to a stressor based on the animals' level of anxiety. For that purpose, the determined phenotypes were compared to match their anxiety levels to changes in their hippocampus and amygdala metabolic profiles. These limbic structures had been selected due to their crucial role in PTSD neurobiology in general and in PTSD anxiety symptomatics in particular.

\section{Materials and methods}

Animal model. The presented study was performed during a spring period using the equipment provided by Center for Genetic Resources of Laboratory Animals, Institute of Cytology and Genetics, SB RAS (RFMEFI61914X0005, RFMEFI62114X0010). The cohort was 26 Sprague-Dawley male rats in the age of $8-9$ weeks by the time the experiments began. The animals were kept in pairs in the OptiRAT ventilated cages (Animal Care, USA). They had free access to water and granulated food (Ssniff, Germany). The cage's photoperiod was 14 light:10 dark, temperature $-24 \pm 2{ }^{\circ} \mathrm{C}$ and humidity $-40-50 \%$. As the nesting material, the cages were inlaid with dedusted wood shavings. Both the food and shavings were autoclaved before use. To water the animals, one used the water cleansed in a Millipore purifier and enriched with the Severyanka mineral additive (ECOPROJECT, Saint-Petersburg). All animal experiments were performed in compliance with the protocols and recommendations for the proper use and care of laboratory animals (ECC Directive $86 / 609 /$ EEC). All efforts were made to minimize the number of animals used and their pain or discomfort.

Research protocol. The animals were divided into $2 \mathrm{sub}-$ groups: control $(n=7)$ and the rats undergoing predator stress to model PTSD $(n=19)$. To model the stress the modified Cohen \& Zohar model (2004) that was previously described in (Tseilikman et al., 2017) was applied. The experimental PTSD model was reproduced through daily exposition of the rats to the urinary marks of a mature domestic cat, deposited on 
softwood cat litter. To do so, Petri dishes with $20 \mathrm{~g}$ of marked litter, covered with nylon fiber were placed in the cages for 15 minutes a day during 10 days. The rats from the control group also had the litter in their cages but without urinary marks. During the next 10 days, the animals experienced no additional exposure, and on day 23 their emotional reactions were estimated using an elevated cross maze (ECM). On day 26 neurometabolite content in their hippocampus and amygdala was estimated. On day 29 the animals were sacrificed.

The rats' behavioral activity. The number of behavioral acts as a response to the stimulus was counted during being exposed to predator stress. Such reactions as fear (a rat stops when passing on feline scent), grooming, explorative reactions (a rat sniffs a Petri dish with urine-marked litter). Other reactions taken into account included evading (a rat diggs the dish into the nesting material); fearlessness (a rat jumps onto the dish); aggression (a rat attacks the dish trying to tear the nylon fiber covering it).

To verify their anxiety, the rats were given an ECM test. The cross maze is a central area of 10 by $10 \mathrm{~cm}$ in size with 4 arms of $50 \times 10 \mathrm{~cm}$ cross-stretching from it, two are placed opposite one another and have no closing walls (open arms) and two other-equipped with closing walls of $50 \mathrm{~cm}$ in height (closed arms). The maze was set at $1 \mathrm{~m}$ above the floor. The individual behavior of each rat was studied in the maze for $10 \mathrm{~min}$. As an integral value characterizing the presence of anxious disorders in the rats, anxiety index (AI) was used that was calculated based on the following formula (Cohen et al., 2008):

$$
\begin{aligned}
& \mathrm{AI}=1-\left(\frac{\text { time in open arms }}{\sum \text { time in maze }}+\right. \\
& \left.+\frac{\text { enters into open arms }}{\sum \text { number of enters }}\right) / 2 .
\end{aligned}
$$

NMR spectroscopy of the hippocampus and amygdala. The content of neurometabolites in the rats' hippocampus and amygdala was studied using a Bruker BioSpec 117/16 USR horizontal tomograph with a magnetic field of 11.7 T. Five minutes prior to the study, the rats were immobilized with gas anesthesia (Isofluran; Baxter Healthcare Corp., Deerfield, IL) using a Univentor 400 Anesthesia Unit (Univentor, Zejtun, Malta). The body temperature of the animals was supported using the water loop of the tomograph's table that warmed its surface to $30^{\circ} \mathrm{C}$. A pneumatic respiration sensor to control the depth of anaesthesia (SA Instruments, Stony Brook, N.Y., USA) was placed underneath each rat.

${ }^{1} H$ MRS. All proton spectra of the rats' brains were obtained using transmitting volume (T11232V3) and receiving surface (T11425V3) ${ }^{1} \mathrm{H}$ RF coils. For proper positioning of the spectroscopic voxels, whose size was $3.0 \times 1.5 \times 3.0 \mathrm{~mm}$ for the amygdala and $1.5 \times 3.0 \times 3.0 \mathrm{~mm}-$ for the hippocampus, TurboRARE, a spin echo technique, was applied $(\mathrm{TE}=11 \mathrm{~ms}$, $\mathrm{TR}=2.5 \mathrm{~ms}$ ) to obtain T2-weighted high-resolution images (slice thickness $-0.5 \mathrm{~mm}$, filed of view $-2.5 \times 2.5 \mathrm{~cm}$, matrix size $-256 \times 256$ pixels) in three projections. All the voxels were positioned manually based on the images obtained. All the proton spectra were obtained using STEAM (stimulated echo acquisition mode spectroscopy; $\mathrm{TE}=3 \mathrm{~ms}, \mathrm{TR}=5 \mathrm{~s}$, and
120 accumulations). Before each spectroscopic measurement, the magnetic field heterogeneity was adjusted for a selected voxel using FastMap (Gruetter, 1993). The water signal in the spectra was suppressed using variable pulse power and optimized relaxation delays (VAPOR) (Tkáč et al., 1999).

${ }^{I} H$ spectra processing. To process the experimental spectra and determine the qualitative content of metabolites, a specially designed software solution was used. As LC Model (Provencher, 1993) the solution assumes that the spectrum of a mixture of known chemical compounds is a linear combination of the spectra of analyzed components. More details about the package can be found in (Moshkin et al., 2014). The percentage content of the studied metabolites was estimated in relation to their total amount. In total, 12 metabolites were studied (N-acetylaspartate, GABA, alanine, aspartate, total choline-containing compounds, total creatine + creatine P, total glutamine + glutamate, myoinositol, taurine, glycine, lactate, phosphorylethanolamine), which allowed for integral estimation of neuronal activity in the rats (Hemanth Kumar et al., 2012; Gulevich et al., 2015; Shevelev et al., 2018) for this set reflects the balance between inhibitory (GABA) and excitatory (glutamine + glutamate) neurotransmitters; contains a neural viability marker ( $\mathrm{N}$-acetylaspartate), key amino acids (alanine and aspartate), moderators of neurotransmission (taurine) and phosphate metabolism (creatine + creatine $\mathrm{P}$ ), and reflects membrane synthesis and cell proliferation (choline, myoinositol and phosphorylethanolamine).

Statistical methods. To process the obtained data, a oneway ANOVA was applied. The significance of the differences between the phenotypes of the studied animals was estimated with a post hoc test (LSD Fisher). The values of the studied parameters were presented as mean \pm standard error of mean $(\mathrm{M} \pm \mathrm{SEM})$.

\section{Results}

Based on their behavioral reactions to the chronic effect of predator stress, the studied rats were separated into two phenotypes. Phenotype $1(n=13)$ exposed a passive defense reaction in which fear and grooming dominated. Phenotype 2 was characterized by active behavioral reactions as absence of fear, aggression towards the stimulus, and searching. On day 13 after the stress exposure was ended (Table 1), statistically significant differences were observed for the time of being in ECM center $\left(\mathrm{F}_{2.24}=5.89, p=0.008\right)$. The post hoc analysis demonstrated statistically significant differences between Phenotype 2 and the control group $(p=0.003)$ as well as between the animals belonging to different phenotypes $(p=0.011)$.

In Phenotype 2 the time of being in ECM center was higher than that in the control rats and Phenotype 1. Moreover, statistically significant differences were observed for the times of being in the open arms $\left(\mathrm{F}_{2.24}=22.32, p<0.001\right)$, which was higher for Phenotype 2 than for the control group $(p<0.001)$ and Phenotype $1(p<0.001)$. In addition, statistically significant differences were observed in the number of the times the animals entered open arms $\left(\mathrm{F}_{2.24}=11.56, p=0.003\right)$. The rats of Phenotype 2 entered them more often than the control rats $(p<0.001)$ and those belonging to Phenotype $1(p<0.001)$.

When studying the metabolite level in the hippocampus (Table 2), significant differences were observed in N-acetyl- 
Table 1. Anxiety indexes in cross-maze test in the rats with different behavioral response to stressor $(M \pm S E M)$

\begin{tabular}{|c|c|c|c|}
\hline Anxiety indexes & $\begin{array}{l}\text { Control } \\
(n=7)\end{array}$ & $\begin{array}{l}\text { Phenotype } 1 \\
(n=13)\end{array}$ & $\begin{array}{l}\text { Phenotype } 2 \\
(n=6)\end{array}$ \\
\hline ECM center, $\%$ of test time & $0.10 \pm 0.02$ & $0.12 \pm 0.02$ & $0.19 \pm 0.01^{* \#}$ \\
\hline Closed arms, $\%$ of test time & $0.86 \pm 0.03$ & $0.83 \pm 0.03$ & $0.62 \pm 0.03^{* \#}$ \\
\hline Open arms, $\%$ of test time & $0.04 \pm 0.01$ & $0.04 \pm 0.01$ & $0.19 \pm 0.03^{* \#}$ \\
\hline Searching in the closed arms, min & $0.92 \pm 0.06$ & $0.94 \pm 0.04$ & $0.98 \pm 0.01$ \\
\hline Searching in the open arms, min & $0.35 \pm 0.06$ & $0.37 \pm 0.03$ & $0.70 \pm 0.06^{* \#}$ \\
\hline Number of enters into the open arms & $0.63 \pm 0.50$ & $0.69 \pm 0.21$ & $4.43 \pm 1.19^{* \#}$ \\
\hline Anxiety index & $0.92 \pm 0.01$ & $0.91 \pm 0.01$ & $0.88 \pm 0.01^{* \#}$ \\
\hline
\end{tabular}

* $p<0.05$ mark the differences when compared to the control; \# $p<0.05$ mark the differences between Phenotypes 1 and 2.

Table 2. Content of neurometabolites in hippocampus and amygdala of the rats with different behavioral response to stressor $(\mathrm{M} \pm \mathrm{SEM})$

\begin{tabular}{|c|c|c|c|c|c|c|}
\hline \multirow[t]{2}{*}{ Neurometabolites } & \multicolumn{3}{|c|}{ Hippocampus } & \multicolumn{3}{|l|}{ Amygdala } \\
\hline & $\begin{array}{l}\text { Control } \\
(n=7)\end{array}$ & $\begin{array}{l}\text { Phenotype } 1 \\
(n=13)\end{array}$ & $\begin{array}{l}\text { Phenotype } 2 \\
(n=6)\end{array}$ & $\begin{array}{l}\text { Control } \\
(n=7)\end{array}$ & $\begin{array}{l}\text { Phenotype } 1 \\
(n=13)\end{array}$ & $\begin{array}{l}\text { Phenotype } 2 \\
(n=6)\end{array}$ \\
\hline N-acetylaspartate & $17.85 \pm 0.67$ & $18.22 \pm 0.68$ & $15.35 \pm 0.53^{* \#}$ & $9.62 \pm 0.83$ & $9.98 \pm 1.13$ & $9.97 \pm 3.02$ \\
\hline GABA & $4.99 \pm 0.68$ & $5.98 \pm 0.96$ & $6.09 \pm 1.17$ & $2.29 \pm 1.09$ & $1.68 \pm 0.51$ & $0.92 \pm 0.66$ \\
\hline Alanine & $4.74 \pm 1.44$ & $3.53 \pm 0.77$ & $5.35 \pm 1.85$ & $0.49 \pm 0.26$ & $2.28 \pm 0.77$ & $1.89 \pm 1.04$ \\
\hline Aspartate & $0.09 \pm 0.01$ & $0.13 \pm 0.03$ & $0.08 \pm 0.01$ & $1.78 \pm 0.93$ & $1.89 \pm 0.89$ & $2.67 \pm 1.47$ \\
\hline $\begin{array}{l}\text { Choline-containing } \\
\text { compounds }\end{array}$ & $1.78 \pm 0.42$ & $1.93 \pm 0.26$ & $1.15 \pm 0.26$ & $1.32 \pm 0.48$ & $1.45 \pm 0.49$ & $0.83 \pm 0.49$ \\
\hline $\begin{array}{l}\text { Creatine }+ \\
\text { phosphocreatine }\end{array}$ & $11.96 \pm 1.19$ & $12.36 \pm 0.84$ & $9.58 \pm 0.84$ & $11.63 \pm 0.90$ & $10.81 \pm 0.83$ & $7.98 \pm 1.81$ \\
\hline $\begin{array}{l}\text { Glutamine + } \\
\text { glutamate }\end{array}$ & $15.07 \pm 1.66$ & $16.90 \pm 1.47$ & $13.43 \pm 1.83$ & $21.27 \pm 2.39$ & $19.81 \pm 1.43$ & $15.37 \pm 4.70$ \\
\hline Myoinositol & $5.46 \pm 1.64$ & $3.83 \pm 1.09$ & $3.48 \pm 1.13$ & $11.14 \pm 3.41$ & $13.74 \pm 2.44$ & $14.11 \pm 4.24$ \\
\hline Taurine & $4.92 \pm 0.55$ & $5.45 \pm 0.48$ & $4.52 \pm 0.42$ & $3.44 \pm 0.52$ & $2.96 \pm 0.84$ & $0.19 \pm 0.13^{* \#}$ \\
\hline Glycine & $19.10 \pm 3.63$ & $21.31 \pm 2.40$ & $20.85 \pm 1.48$ & $12.86 \pm 4.15$ & $8.30 \pm 3.57$ & $9.84 \pm 5.77$ \\
\hline Lactate & $4.44 \pm 1.01$ & $1.90 \pm 0.83$ & $6.26 \pm 1.53^{\#}$ & $1.08 \pm 1.00$ & $5.32 \pm 3.35$ & $2.35 \pm 2.06$ \\
\hline Phosphorylethanolamine & $9.59 \pm 3.12$ & $8.63 \pm 2.14$ & $13.30 \pm 1.74$ & $23.09 \pm 3.39$ & $22.00 \pm 2.80$ & $33.18 \pm 7.17$ \\
\hline
\end{tabular}

* $p<0.05$ mark the differences when compared to the control; $\# p<0.05$ mark the differences between Phenotypes 1 and 2.

aspartate $\left(\mathrm{F}_{2.24}=3.74, p=0.041\right)$ and lactate $\left(\mathrm{F}_{2.24}=4.42\right.$, $p=0.023)$ contents. It turned out that $\mathrm{N}$-acetylaspartate content in Phenotype 1 was higher than that in Phenotype 2 $(p=0.014)$. However, when compared to the control, no significant differences were seen. On the other hand, the lactate content in Phenotype 2 was higher than that of Phenotype 1 $(p<0.01)$ with no statistical differences registered against the control.

When studying the metabolite level in the amygdala (see Table 2), statistically significant differences were observed only for taurine content $\left(\mathrm{F}_{2.24}=3.51, p=0.049\right)$. It was lowest in Phenotype 2 and statistically differed from both the control $(p=0.022)$ and Phenotype $1(p=0.031)$.

\section{Discussion}

First hand, the obtained results attest there is a link between a behavioral reaction to stress and the anxiety level registered long after the stress. It is noteworthy that in the experiment, the anxiety level in the control rats was initially high. According to other studies (Cohen, Zohar, 2004; Kondashevskaya et al., 2017) using this index, its mean value usually varies from 0.5 to 0.75 , although there were those whose anxiety index exceeded 0.8 . In our design, the initial level of anxiety was so high that even daily predator stress could not worsen it.

So far, the rats included in Phenotype 2 that demonstrated active behavior (S-R strategy) in response to the predator 
stress had a lower level of anxiety if compared to the control group, while the rats belonging to Phenotype 1 with passive behavior (S strategy) preserved the high level of anxiety even when being no longer exposed to the stress. In other words, the anxiolytic effect of the stress was observed only in the rats using S-R strategy. Thus, the experiment has demonstrated the role of an animal's initial condition in the formation of the long-term effects of chronic predator stress.

For the time being, there have only been a few studies investigating changes in the level of brain metabolites in animal models in the presence of chronic stress. The discovered difference in the behavioral reactions of rats to predator stress has found their reflection in metabolic changes in certain structures of the brain. Our results obtained for certain hippocampal metabolites have demonstrated that $\mathrm{N}$-acetylaspartate responsible for the general viability of neurons (Moffett et al., 2007; Shevelev et al., 2018) reduces in Phenotype 2 (S-R strategy) to lower extend if compared both to Phenotype 1 (S strategy) and the control rats. These results are comparable to the ones obtained by Hemanth Kumar et al. (2012), who studied chronic stress in a rat model and observed reduction of the same metabolite in the hippocampus. Similar reduction of $\mathrm{N}$-acetylaspartate level was reported for the hippocampus of stressed macaques (Coplan et al., 2010). Hemanth Kumar et al. (2012) also demonstrated that in presence of chronic stress, rats had increased hippocampal taurine levels. In our study, a similar tendency has been demonstrated by the rats belonging to Phenotype 1 if compared to the control group, but these differences have not been statistically significant.

Another interesting peculiarity of the rats using S-R strategy has been a higher level of lactate if compared to the other experimental group. Meanwhile, being exposed to the stimulus only active (S-R) rats have shown signs of aggression. Opposite data were obtained for the grey rats selected for their aggressive defense reaction to humans. As it turned out, domestic rats had a higher level of hippocampal lactate if compared to these aggressive rats (Gulevich et al., 2015).

Among the studied neurometabolites of the amygdala, only taurine has been sensitive to predator stress. Its content has reduced in the active rats of Phenotype 2 if compared both to Phenotype 1 and the control group. In this respect, it is important to note that taurine modulates neurosynaptic transmission (McCool, Chappell, 2007), so its lower level may be indirect evidence of reduced amygdala activity in Phenotype 2. And, possibly, this reduction is one of the chains of the mechanism producing the anxiolytic effect in this predator stress model.

\section{Conclusion}

Finding this effect in the rats using S-R strategy while stressed has been the main scientific novelty of the performed study, in which we have been able to detect informative neurometabolites in the rats demonstrating different behavioral reactions under stress. If one assumes there is a link between this experimental reduction of anxiety in rats and posttraumatic stress disorder in humans, our experimental protocol can be used for future development and validation of a model that characterizes this underinvestigated consequence of phycological trauma.

\section{References}

American Psychiatric Association. Diagnostic and Statistical Manual of Mental Disorders, Fifth Edition (DSM-5). Arlington, V.A.: Amer. Psychiatric Publ., 2013.

Cohen H., Matar M.A., Buskila D., Kaplan Z., Zohar J. Early poststressor intervention with high-dose corticosterone attenuates posttraumatic stress response in an animal model of posttraumatic stress disorder. Biol. Psychiatry. 2008;64:708-717. DOI 10.1016/j.biopsych. 2008.05.025.

Cohen H., Zohar J. An animal model of posttraumatic stress disorder: the use of cut-off behavioral criteria. Ann. NY Acad. Sci. 2004;1032:167-178. DOI 10.1196/annals.1314.014.

Coplan J.D., Mathew S.J., Abdallah C.G., Mao X., Kral J.G., Smith E.L., Rosenblum L.A., Perera T.D., Dwork A.J., Hof P.R., Gorman J.M., Shungu D.C. Early-life stress and neurometabolites of the hippocampus. Brain Res. 2010;1358:191-199. DOI 10.1016/ j.brainres.2010.08.021.

De Kloet E.R. From receptor balance to rational glucocorticoid therapy. Endocrinology. 2014;155(8):2754-2769. DOI 10.1210/en.20141048.

Gruetter R. Automatic, localized in vivo adjustment of all first- and second-order shim coils. Magn. Reson. Med. 1993;29:804-811.

Gulevich R.G., Akulov A.E., Shikhevich S.G., Kozhemyakina R.V., Plyusnina I.Z. Proton magnetic resonance spectroscopy of neurometabolites in the hippocampi of aggressive and tame male rats. Russ. J. Genet.: Appl. Res. 2016;6(4):430-436. DOI 10.1134/ S2079059716040079.

Hemanth Kumar B.S., Mishra S.K., Rana P., Singh S., Khushu S. Neurodegenerative evidences during early onset of depression in CMS rats as detected by proton magnetic resonance spectroscopy at $7 \mathrm{~T}$. Behav. Brain Res. 2012;232(1):53-59. DOI 10.1016/j.bbr.2012. 03.011 .

Kondashevskaya M.V., Tseilikman V.E., Manukhina E.B., Downey H.F., Komelkova M.V., Lapshin M.S., Samoylov E.A., Popkov P.N., Aliluev A.V., Vasileva M.V., Kurganov A.S., Maltseva N.V., Tseilikman O.B. Disorder in the morphology and function of adrenal glands in experimental post-traumatic stress disorder in rats: correlation with behavioral markers. Rossiyskiy Fiziologicheskiy Zhurnal im. I.M. Sechenova = I.M. Sechenov Physiological Journal. 2017;103(7):808-818. (in Russian)

McCool B.A., Chappell A. Strychnine and taurine modulation of amygdala-associated anxiety-like behavior is 'state' dependent. Behav. Brain Res. 2007;178(1):70-81. DOI 10.1016/j.bbr.2006.12.002.

Moffett J.R., Ross B., Arun P., Madhavarao C.N., Namboodiri A. N-Acetylaspartate in the CNS: from neurodiagnostics to neurobiology. Prog. Neurobiol. 2007;81:89-131. DOI 10.1016/j.pneurobio. 2006. 12.003 .

Moshkin M.P., Akulov A.E., Petrovski D.V., Saik O.V., Petrovsky E.D., Savelov A.A., Koptyug I.V. Proton magnetic resonance spectroscopy of brain metabolic shifts induced by acute administration of 2-deoxi-D-glucose and lipopolisacharides. NMR Biomed. 2014; 27(4):399-405. DOI 10.1002/nbm.3074.

Pitman R., Rasmusson A., Koenen K., Shin L., Orr S., Gilbertson M., Milad M., Liberzon I. Biological studies of post-traumatic stress disorder. Nat. Rev. Neurosci. 2012;13:769-787. DOI 10.1038/nrn 3339.

Provencher S.W. Estimation of metabolite concentrations from localized in vivo proton NMR spectra. Magn. Reson. Med. 1993;30(6):672-679.

Schwabe L., Dalm S., Schachinger H., Oitzl M.S. Chronic stress modulates the use of spatial and stimulus-response learning strategies in mice and man. Neurobiol. Learn. Mem. 2008;90(3):495-503. DOI 10.1016/j.nlm.2008.07.015.

Shevelev O.B., Seryapina A.A., Zavjalov E.L., Gerlinskaya L.A., Goryachkovskaya T.N., Slynko N.M., Kuibida L.V., Peltek S.E., Markel A.L., Moshkin M.P. Hypotensive and neurometabolic effects of intragastric Reishi (Ganoderma lucidum) administration in hypertensive ISIAH rat strain. Phytomedicine. 2018;41:1-6. DOI 10.1016/j.phymed.2018.01.013. 
Tkáč I., Starčuk Z., Choi I.-Y., Gruetter R. In vivo ${ }^{1} \mathrm{H}$ NMR spectroscopy of rat brain at $1 \mathrm{~ms}$ echo time. Magn. Reson. Med. 1999;41:649656.

Tseilikman V.E., Shevelev O.B., Khotskin N.V., Dotsenko A.S., Kontsevaya G.V., Lapshin M.S., Moshkin M.P., Komelkova M.V., Feklicheva I.V., Tseilikman O.B., Dremencov E., Zavjalov E.L. Magnetic resonance spectroscopy of hippocampal and striatal neuro- metabolites in experimental PTSD rat modeling. Vavilovskii Zhurnal Genetiki i Selektsii = Vavilov Journal of Genetics and Breeding. 2017;21(7):783-787. DOI 10.18699/VJ17.293. (in Russian)

Wong A., Lee H.S., Lee H.P., Choi Y.K., Lee J.H. Posttraumatic stress disorder symptoms and posttraumatic growth following indirect trauma from the Sewol ferry disaster, 2014. Psychiatry Investig. 2018;15(6):613-619. DOI 10.30773/pi.2017.12.03.

ORCID ID

O.B. Shevelev orcid.org/0000-0003-3200-958X

E.L. Zavjalov orcid.org/0000-0002-9412-3874

Acknowledgements. The animals and behavioral testing are supported by the budget project (No. 0324-2019-0041). The MRI study is supported by the budget project (No. 0259-2019-0004). All studies are implemented using the equipment of Center for Genetic Resources of Laboratory Animals at ICG SB RAS, supported by the Ministry of Education and Science of Russia (Unique ID\# of the project: RFMEFI62117X0015).

Conflict of interest. The authors declare no conflict of interest.

Received March 4, 2019. Revised May 8, 2019. Accepted May 12, 2019. 